\title{
Development of artistic abilities of preschool and primary school age children in the digital educational environment of additional education
}

\author{
Svetlana Emanova, Anastasia Ryleeva , and Elena Khomutnikova, and Natalia Komarova, \\ and Natalia Usynina
}

Kurgan State University, Kurgan, Russia

\begin{abstract}
With the help of the technology of operational diagnostics of artistic abilities, the potential inclinations of artistic and creative activity in children of preschool and primary school age were identified and the range of identified interests in additional education programs was realized. Two groups of respondents of different ages were examined: 6-7 years old in the amount of 45 persons, 9-11 years old in the amount of 85 persons. In the course of the study, it was concluded that the technology of operative diagnostics of artistic abilities is effective at any of these ages. There is a correlation between the motivational and operational readiness of the individual and the success of artistic and creative activity. We have selected the most effective forms of virtual education for the successful development of children's artistic abilities.
\end{abstract}

\section{Introduction}

One of the leading trends in the development of the modern educational space in Russia is to ensure the free and harmonious development of the individual, active participation in society. According to the Decree of the President of the Russian Federation of July 21, 2020 No. 474 "About the national development goals of the Russian Federation for the period up to 2030 ", the national goal is to provide opportunities for self-realization and development of talents. The digital educational environment makes it possible to realize the national goal, especially in the system of additional education. By the digital educational environment of continuing education, we mean a complex software solution that includes technologies, technical means, services and resources (digital educational resources - developing educational content), uniting participants of the educational process. The content provides emotional comfort for the child by taking into account the individual characteristics of the child, implementing the principle of individualization and personalization of preschool education. Additional education is a continuous process. It has no fixed deadlines and sequentially moves from one stage to another. The individual and personal basis of the activity of institutions of this type allows satisfying the needs of any category of children.

\footnotetext{
*Corresponding author: ib.75@ mail.ru
} 
The peculiarities of the educational process here is an informal style of relationships among students, students and teachers themselves, relations of cooperation and co-creation.

It is such an educational environment that stimulates the children's initiative, creates a sense of well-being, pleasure from the learning process, the need to express one's point of view, to try something new. Creating a situation of success as the leading principle of continuing education, develops abilities, shapes the needs of creative activity. Therefore, the system of additional education can be considered a resource for identifying and developing abilities.

The digital educational environment of the additional education system, having sufficient potential to make a creative space, opens up wide opportunities for the manifestation of initiative and activity of each individual.

Preschool and primary school age is considered a unique period in the development and formation of the child's personality. In this age period, it is necessary to pay close attention to the development of the basic personal structures necessary for the successful socialization and adaptation of a growing person, the development of his abilities [9].

Specialists in the field of psychology of creativity, abilities and giftedness (L.S. Vygotsky, P.Y. Halperin, A.V. Zaporozhets, S.N. Karpova, N.S. Leites, S.L. Rubinshtein, B.M. Teplov, etc.) revealed a number of criteria by which one can judge the severity of abilities in a person - the effectiveness of the activity, the speed and success of mastering the necessary knowledge and skills, the originality and originality of the work, as well as the degree of overcoming adverse environmental conditions [7].

If B.M. Teplov defined abilities as individual psychological characteristics of a person related to the success of any activity or many [2], then S.L. Rubinstein as "properties or qualities that make a person fit for the successful implementation of any type of socially useful activity" [3].

As noted by L.S. Vygotsky "all the child's abilities develop in his interaction with the environment, in games and activities, under the influence of instruction and upbringing" $[5,6]$, in other words, "the ability cannot arise outside the corresponding concrete activity" [4].

Abilities, therefore, are a process of intravital formation. In this regard, the diagnosis of abilities should also be a process consisting of interconnected levels of cognition.

To study abilities, researchers use various methods: observation, natural experiment, analysis of activity products, expert evaluations of specialists. As a rule, according to formal criteria, these methods are not brought up to the level of requirements for psychodiagnostic methods. Foreign researchers have the most developed problem of the diagnosis of special abilities [8].

In the theory and practice of art education, diagnostics was adopted, based on the identification of three basic abilities - intellectual and creative potential; musical and motor capabilities; a complex of motivational-personal properties [6].

Comparing the points of view of different authors on general and special abilities, and comparing theoretical material with pedagogical experience in identifying and developing artistic abilities in children in the context of additional education, it became necessary to identify the role of operational creative diagnostics in the process of introducing children to artistic creativity in an institution of additional education.

\subsection{Research results}

Based on the idea of B.M. Teplov that abilities are not limited to the presence of skills, abilities and knowledge, but can explain the ease and speed of their acquisition [2], we have selected a set of play techniques, including virtual ones, for the program of operational and creative diagnostics of artistic abilities. The technology of operational creative diagnostics is 
based on the principle of "during studying we develop children and motivate them". It is used for the initial study of the interests of preschoolers and primary schoolchildren in order to consolidate them in programs of additional education [9].

The main goal of this work: to check the effectiveness of the technology of operationalcreative diagnostics itself in determining the artistic abilities of children in a sensitive period of development, the levels of readiness of preschoolers and primary schoolchildren to engage in artistic creativity and defining this technology as a way of integrating schools and institutions of additional education in digital educational environment. To achieve the goal, a pedagogical experiment was conducted, which took place in the MBOU "Secondary School No. 49", the city of Kurgan, the art school of the working village of Vargashi, Kurgan region. For the study, a group of preschoolers from the art school was taken in the amount of 45 persons and 85 schoolchildren of 3 classes of a comprehensive school.

During the experiment, participants conducted collective and individual-group classes to diagnose the level of development of artistic abilities in accordance with the program, which included three diagnostic blocks: musical abilities, choreographic abilities, personality characteristics. The information received over 3 classes on the level of basic abilities of children was recorded in a special individual map.

The system of test tasks in kahoot.com mode was aimed at studying the structural components of artistic abilities: sound-altitude, tempo-metro-rhythmic, timbre, dynamic, harmonic (mode), sense of form; endurance, mobility of the spinal column, musical and rhythmic coordination, stage performance ability, creative imagination, the ability to improvise; emotional responsiveness, as well as the cognitive, operational and motivational components of the artistic and aesthetic tastes of children.

Initial tests allow us to ascertain the presence of certain abilities in subjects, but do not determine the success of their subsequent training. Assessment of development prospects is possible only after distributing children in creative associations. Nevertheless, the data obtained allow us to determine the direction of work with each child, depending on individual results. This technique allows us to present the level of manifestation of structural characteristics and serves as a support in building an individual route for the creative development of each child. The test score is expressed in three levels: high, medium, low.

High level - creative activity, independence, initiative; quick understanding of the task, its exact expressive performance without the help of an adult; pronounced emotionality.

Average level - emotional responsiveness, interest, a desire to join in the proposed activity. However, difficulties in completing the assignment. The help of the teacher is required.

Low level - unemotional; "smooth", calmly related to activities, no active interest, indifferent. A person is not capable for independence.

\section{Figures and tables}

The final indicators of the development of the components of artistic abilities were entered in the virtual individual card of the participant "Diagnostic Designer" (Table 1). 
Table 1. Diagnostic Designer of Artistic Abilities.

\begin{tabular}{|c|c|c|c|c|c|c|c|c|c|c|c|c|c|c|c|c|c|c|}
\hline \multirow{3}{*}{$\begin{array}{l}\text { Level } \\
\text { of } \\
\text { devel } \\
\text { op- } \\
\text { ment }\end{array}$} & \multicolumn{18}{|c|}{1 Musical Abilities Parameters } \\
\hline & \multicolumn{3}{|c|}{$\begin{array}{l}\text { Metro } \\
\text { pace } \\
\text { rhythm }\end{array}$} & \multicolumn{3}{|c|}{$\begin{array}{l}\text { Sense of } \\
\text { timbre }\end{array}$} & \multicolumn{3}{|c|}{$\begin{array}{c}\text { Sense of } \\
\text { sound- } \\
\text { altitude }\end{array}$} & \multicolumn{3}{|c|}{$\begin{array}{c}\text { Sense of } \\
\text { harmon } \\
y\end{array}$} & \multicolumn{3}{|c|}{$\begin{array}{l}\text { Sense of } \\
\text { dynami }\end{array}$} & \multicolumn{3}{|c|}{ Sense of form } \\
\hline & 1 & 2 & 3 & 1 & 2 & 3 & 1 & 2 & 3 & 1 & 2 & 3 & 1 & 2 & 3 & 1 & 2 & 3 \\
\hline High & & & & & & & + & + & + & & & & & & & & & \\
\hline $\begin{array}{c}\text { Avera } \\
\text { ge }\end{array}$ & & & & & & & & & & + & + & + & + & + & + & + & + & \\
\hline Low & + & + & + & + & + & + & & & & & & & & & & & & + \\
\hline
\end{tabular}

Table 2. Diagnostic Choreographic Abilities Parameters.

\begin{tabular}{|c|c|c|c|c|c|c|c|c|c|c|c|c|c|c|c|c|c|c|}
\hline \multirow{3}{*}{$\begin{array}{c}\text { Level } \\
\text { of } \\
\text { devel } \\
\text { op- } \\
\text { ment }\end{array}$} & \multicolumn{18}{|c|}{ 2. Choreographic Abilities Parameters } \\
\hline & \multicolumn{3}{|c|}{$\begin{array}{c}\text { Enduran } \\
\text { ce }\end{array}$} & \multicolumn{3}{|c|}{ Mobility } & \multicolumn{3}{|c|}{$\begin{array}{c}\text { Coordinatio } \\
\mathrm{n}\end{array}$} & \multicolumn{3}{|c|}{$\begin{array}{c}\text { Stage } \\
\text { performan } \\
\text { ce ability }\end{array}$} & \multicolumn{3}{|c|}{$\begin{array}{c}\text { Creative } \\
\text { imagination }\end{array}$} & \multicolumn{3}{|c|}{ Impro-visation } \\
\hline & 1 & 2 & 3 & 1 & 2 & 3 & 1 & 2 & 3 & 1 & 2 & 3 & 1 & 2 & 3 & 1 & 2 & 3 \\
\hline High & & & & & & & + & + & + & & & & & & & & & \\
\hline $\begin{array}{c}\text { Avera } \\
\text { ge }\end{array}$ & & & & & & & & & & + & + & + & + & + & + & + & + & \\
\hline Low & + & + & + & + & + & + & & & & & & & & & & & & + \\
\hline
\end{tabular}

Table 3. Diagnostic Personal characteristics.

\begin{tabular}{|c|c|c|c|c|c|c|c|c|c|c|c|c|c|}
\hline \multirow{3}{*}{$\begin{array}{c}\text { Level } \\
\text { of } \\
\text { develop } \\
\text {-ment }\end{array}$} & \multirow{2}{*}{\multicolumn{3}{|c|}{$\begin{array}{c}\text { Emotional } \\
\text { responsivenes } \\
\mathrm{s}\end{array}$}} & \multicolumn{9}{|c|}{ 3. Personal characteristics } & \multirow{3}{*}{$\begin{array}{l}\text { Sum- } \\
\text { mary } \\
\text { data }\end{array}$} \\
\hline & & & & \multicolumn{3}{|c|}{$\begin{array}{c}\text { Motivational } \\
\text { component }\end{array}$} & \multicolumn{3}{|c|}{$\begin{array}{l}\text { Cognitive } \\
\text { component }\end{array}$} & \multicolumn{3}{|c|}{$\begin{array}{c}\text { Operational } \\
\text { component }\end{array}$} & \\
\hline & 1 & 2 & 3 & 1 & 2 & 3 & 1 & 2 & 3 & 1 & 2 & 3 & \\
\hline High & + & & & & & & & & & & & + & 4 \\
\hline $\begin{array}{c}\text { Averag } \\
\mathrm{e}\end{array}$ & & + & + & + & + & + & + & + & + & + & + & & 19 \\
\hline Low & & & & & & & & & & & & & 7 \\
\hline
\end{tabular}

After analysis of the diagnostic data, group results were determined (Table 4).

Table 4. The level of manifestation of the parameters of artistic abilities (group metric).

\begin{tabular}{|c|c|c|c|}
\hline \multirow{2}{*}{ № } & Artistic Abilities & \multicolumn{2}{|c|}{ Ability level } \\
\cline { 3 - 4 } & $\begin{array}{c}\text { Parameters } \\
\text { Pense of the metro - } \\
\text { tempo rhythm }\end{array}$ & Preschoolers & $\begin{array}{c}\text { Primary } \\
\text { schoolchildren }\end{array}$ \\
\hline 1 & Sense of timbre & Average & Average \\
\hline 2 & Sverage \\
\hline 3 & Sense of sound-altitude & Average & Average \\
\hline 4 & Sense of harmony & Average & Average \\
\hline 5 & Sense of dynami & Average & Average \\
\hline 6 & Sense of form & Low & Average \\
\hline 7 & Endurance & Low & High \\
\hline 8 & Mobility & High & High \\
\hline 9 & Coordination & Low & High \\
\hline 10 & Stage performance ability & High & High \\
\hline 11 & Creative imagination & High & High \\
\hline 12 & Improvisation & High & High \\
\hline
\end{tabular}


Continuation of table 4.

\begin{tabular}{|l|c|c|c|}
13 & Emotional responsiveness & High & High \\
\hline 14 & Motivational component & Low & High \\
\hline 15 & Operational component & Low & High \\
\hline 16 & Cognitive component & Low & High \\
\hline
\end{tabular}

After analysis of the diagnostic data, group results were determined (Table 5).

Table 5. The level of manifestation of the parameters of artistic abilities

(group metric).

\begin{tabular}{|c|c|c|c|}
\hline \multirow{2}{*}{ № } & Artistic Abilities Parameters & \multicolumn{2}{c|}{ Ability level } \\
\cline { 3 - 4 } & & Preschoolers & $\begin{array}{c}\text { Primary } \\
\text { schoolchildre } \\
n\end{array}$ \\
\hline 1 & & & Average \\
\hline 2 & Sense of the metro - tempo rhythm & Low & Average \\
\hline 3 & Sense of timbre & Average & Average \\
\hline 4 & Sense of sound-altitude & Average & Average \\
\hline 5 & Sense of harmony & Average & Average \\
\hline 6 & Sense of dynami & Average & Average \\
\hline 7 & Sense of form & Low & High \\
\hline 8 & Endurance & Low & High \\
\hline 9 & Mobility & High & High \\
\hline 10 & Coordination & Low & High \\
\hline 11 & Stage performance ability & High & High \\
\hline 12 & Creative imagination & High & High \\
\hline 13 & Improvisation & High & High \\
\hline 14 & Emotional responsiveness & Low & High \\
\hline 15 & Motivational component & Low & High \\
\hline 16 & Operational component & Low & Cognitive component \\
\hline
\end{tabular}

As can be seen on the table, preschoolers at a low level have two parameters of musical abilities (metro rhythm and sense of form), coordination and endurance - choreographic abilities and indicators of the personality block - motivational, operational and cognitive components. In primary schoolchildren, 10 out of 16 indicators of the parameters of artistic abilities are registered at a high level. That shows us about the dynamism of the development of abilities from preschool to primary school age.

Two groups were selected from the total number of diagnostic participants: preschool children in the amount of 12 persons and primary school children in the amount of 24 persons with good indicators to identify their readiness for artistic and creative activities (Table 6).

Table 6. The level of readiness of children for artistic and creative activities

\begin{tabular}{|c|c|c|c|c|c|}
\hline \multirow{2}{*}{ № } & Level of readiness & \multicolumn{2}{|c|}{ Preschoolers } & \multicolumn{2}{c|}{$\begin{array}{c}\text { Primary } \\
\text { schoolchildren }\end{array}$} \\
\cline { 3 - 6 } & & Absolute & In \% (relative) & $\begin{array}{c}\text { Absol } \\
\text { ute }\end{array}$ & $\begin{array}{c}\text { In \% } \\
\text { (relative } \\
\text { ) }\end{array}$ \\
\hline 1 & High & 2 & $16,67 \%$ & 15 & $62,5 \%$ \\
\hline 2 & Average & 7 & $58,33 \%$ & 5 & $20,8 \%$ \\
\hline 3 & Low & 3 & $25 \%$ & 4 & $16,67 \%$ \\
\hline
\end{tabular}

Both senior preschoolers and primary schoolchildren showed a willingness to engage in artistic and creative activities. However, high level of readiness for preschool children is $16.67 \%$, and for elementary school students is $62.5 \%$. 
The result of operational diagnostics was to be the consolidation of children in sections and associations of an artistic orientation (music, choreography, rhythm, theatrical activity) (Fig. 1).

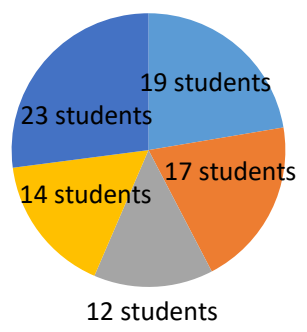

$$
\begin{aligned}
& \text { "Musical Theatre" } \\
& \text { "Dance world" } \\
& \text { "Domisolka" }
\end{aligned}
$$

12 students

Fig. 1. Involving (fixing) children in artistic associations

Out of 85 students in Secondary School No. 49, 62 children became participants in creative associations. All children are involved in extracurricular activities of the school, such as: participation in concerts, creative contests etc.

These forms are held in a distance format based on gamification technologies through zoom, through the website of the educational organization, the blog and pages of teachers, where materials with master classes, workshops and trainings, creative educational games (for example, "Danetki", live action games) are posted, watching interactive videos YouTube, WhatsApp.

The result of the diagnosis in preschool children involved in choreography in the preparatory group was an increase in the motivational component (Fig. 2).

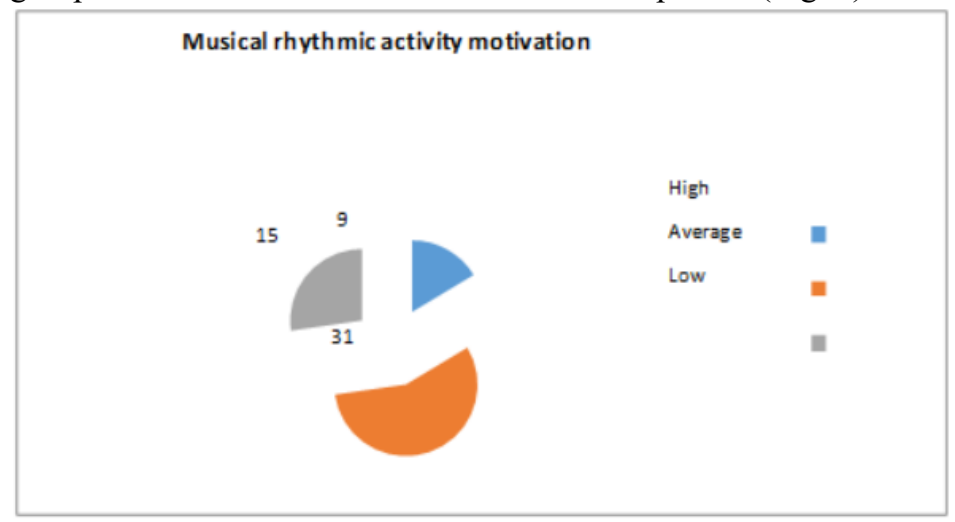

Fig. 2. The results of the level of motivation for the musical and rhythmic activity of preschoolers after operational-creative diagnosis.

9 children were identified with a high level, 31 children with an average and 5 children with a low level of motivation for musical rhythmic activity. A significant level of motivation served as the basis for the further consolidation of children in the selected types of artistic activity. As a rule, preschool children are included in such types of virtual learning as: creative quests, travel workshops, master classes on the development of artistic abilities, interactive games.

\section{Conciusions}

The technology of operational creative diagnostics in the system kahoot.com allows us to identify the levels of various components of artistic abilities in children of preschool and 
primary school age, which makes it possible not only free but also the right choice for the child and the parent of the program profile, its inclusion in various types of creative activity, taking into account individual inclinations and differences, makes it possible to create a personal success situation for each child.

This diagnosis at the early stage of primary education acts as a basic component of the integration of the school and the institution of additional education in the organization of extracurricular activities of primary schoolchildren.

The involvement of children in non-standard virtual forms leads to an increase in the motivation and creative activity of children of preschool and primary school age.

\section{References}

1. S.V. Emanova, E.A. Khomutnikova, World of Science, Culture, Education 5(72), 156 (2018)

2. B.M. Teplov, Abilities and giftedness, 91 (2012)

3. Rubinstein Psychology of giftedness of children and adolescents, ed. M.S. Leites, Moscow: Ed. "Academy", 1996. 416 p.

4. L.S. Vygotsky, Collected works, M. Pedagogika, 540 p. (2012)

5. E.R. Polovinko, Bulletin of the Bashkir University 19(1), 265 (2014)

6. P.Ya. Galperin, A.V. Zaporozhets, S.N. Karpov, Actual problems of age-related psychology, Moscow: Moscow State University (2011)

7. Development of musical abilities of primary schoolchildren. http://knowledge.allbest.ru.

8. S.V. Emanova, M.A. Sokolskaya, E.A. Kazantseva, Organization of pedagogical support in the process of creative activity of preschoolers and primary schoolchildren in the context of additional education for children and adults. Human education in the era of global transformations: materials of the Int. Scientific and Practical Conf., 131 (2018)

9. A.S. Ryleeva, S.V. Emanova, Bulletin of the University of the Russian Academy of Education 4, 36 (2019) 